\title{
Assessment of Tourism industry in Nueva Ecija
}

\section{Aileen Y. Vigilia}

Nueva Ecija University of Science and Technology, Philippines

\begin{abstract}
Tourism plays an important role in establishing a nation like the Philippines and serves as one of the state's contributor. A total of 205 tourist respondents were surveyed from different tourist spots in Nueva Ecija. Descriptive method of research was used. Also, the researcher used likert-scale type questionnaire and analyzed the data through statistical data treatment such as mean and weighted mean. In light of the foregoing results, the researcher concluded that the tourist spots in Nueva Ecija greatly appealed its visitors through its uniqueness, historical value and natural aesthetics and were evaluated as "Excellent." Thus, the accessibility to these tourist spots was evaluated as "Fair."Further, the difficulties and problems encountered by tourists, in terms of "Transportation" was evaluated as "Fair." Thus, the areas for the development of tourism should focus more on improving the aspect transportation than tourism service facility as this aspect was evaluated as "Excellent."
\end{abstract}

Keywords - Tourism, Tourist Spots, Assessment, Tourist Industry.

\section{INTRODUCTION}

Tourism plays an important role in establishing a nation like the Philippines and serves as one of the state's contributor. Lickorish and Jenkins (2007) stated that the government has often played a supporting but largely background role in the development of tourism, particularly in the developed countries. Further, Rodolfo (2009) cited as one of tourism's benefits is that the achievement of tourism development will heighten their national identity and sense of unity.

According to Said (2008), tourist spots boasts environmental features that cater to ecotourism, maritime as well as community-based tourism, so steps must be taken to conserve its infrastructure and culture that can potentially be lost if no effort is made to protect such attractions.

Aguda et al. concluded that the respondents accepted that the impacts of tourism on tourist spots in province are financial, economic, political, educational, heritage and the arts. Thus, De Vera (2019) revealed that the tourist definition of what is the optimal distance and space to another unknown tourist can be decreased as shown in the effects of the tourists ' measured limits and real maps, thereby minimizing the tourists ' social and public spaces.

Celis et al. (2013) concluded that the prospect of tourism attraction business development is high, as people's love for travel and tours will remain a part of their psyche. Likewise, Ylagan and Laguador (2014) suggested that each municipality's Local Government Units improve the tourism development programs in collaboration with the private sectors.
In view of these insights, the researcher wanted to assess the tourism in Nueva Ecija as the province is home to different tourist spots such as Minalungao, and other mountain scenic spots.

\section{CONCEPTUAL FRAMEWORK}

According to Jian-ying (2007), Tourism assets values include importance of tourism, value of scientific research, historical culture and value of education, value of the environment, value of the opportunity, value of the heritage and value of life.

Su and Wall (2010) concluded that most respondents agreed that encounters with local people have an effect on their destination perceptions, the nature of their visits, potential destination choices and on-site purchases, particularly those with higher education and a younger age.

Further, Aguila and Ragot (2014) concluded that building roads and bridges can help to boost a province's ecotourism industry as it can help improve access to the tourist destination.

\section{OBJECTIVES OF THE STUDY}

The study described the assessment of tourist spots in Nueva Ecija in terms of appeal, accessibility, activities and products, and, facilities and services. This paper also described the difficulties and problems encountered by the tourists in terms of transportation, tourism service facilities, accommodation establishments and infrastructure. 


\section{METHODOLOGY}

The study used descriptive method as it describes the present condition. The main objective of the study is to explore the causes of particular phenomenon with effects that being felt or trends that are developing. (Cohen, Manion, Morrison, 2002)

A total of 205 tourist respondents were surveyed from different tourist spots in Nueva Ecija.The researcher used likert-scale type questionnaire (Vagias, 2006) and analyzed it through statistical data treatment such as mean and weighted mean.

\section{RESULTS AND DISCUSSION}

Table 1. Tourist Spots' Appeal

\begin{tabular}{|l|l|l|}
\hline Statements & $\begin{array}{l}\text { Weighted } \\
\text { Mean }\end{array}$ & $\begin{array}{l}\text { Verbal } \\
\text { Interpretation }\end{array}$ \\
\hline $\begin{array}{l}\text { The tourist spots do not have } \\
\text { similarities to other province's } \\
\text { tourist spot. (Uniqueness) }\end{array}$ & 3.52 & $\begin{array}{l}\text { Strongly } \\
\text { Agree }\end{array}$ \\
\hline $\begin{array}{l}\text { The tourist spots have been } \\
\text { well-preserved for its years of } \\
\text { existence. (Historical Value) }\end{array}$ & 3.42 & $\begin{array}{l}\text { Strongly } \\
\text { Agree }\end{array}$ \\
\hline $\begin{array}{l}\text { The inhabitants of the tourist } \\
\text { spots preserve their tradition } \\
\text { and customs. (Socio-Cultural } \\
\text { Value) }\end{array}$ & 3.09 & Agree \\
\hline $\begin{array}{l}\text { The tourist spots were } \\
\text { preserved with its nature beauty } \\
\text { and not enhanced with modern } \\
\text { day construction materials. } \\
\text { (Natural Aesthetic) }\end{array}$ & 3.34 & Strongly \\
\hline $\begin{array}{l}\text { There were 100,000 and more } \\
\text { tourists/visitors per annum } \\
\text { tallied in the tourist spots of the } \\
\text { province. (Presence of Visitor } \\
\text { Traffic) }\end{array}$ & 2.81 & Agree \\
\hline $\begin{array}{l}\text { Total Weighted Mean } \\
\text { Talee }\end{array}$ & 3.24 & $\begin{array}{l}\text { Strongly } \\
\text { Agree }\end{array}$ \\
\hline
\end{tabular}

Table 1 presents that the statement, "The tourist spots do not have similarities to other province's tourist spot" which represents Uniqueness got the highest weighted mean of 3.52 with verbal interpretation, "Strongly Agree." While the statement, "There were 100,000 and more tourists/visitors per annum tallied in the tourist spots of the province" which represents the presence of visitor traffic got the lowest weighted mean of 2.81 with verbal interpretation, "Agree."
Table 2. Tourist spots' Accessibility

\begin{tabular}{|l|l|l|}
\hline Statements & $\begin{array}{l}\text { Weighted } \\
\text { Mean }\end{array}$ & $\begin{array}{l}\text { Verbal } \\
\text { Interpretation }\end{array}$ \\
\hline $\begin{array}{l}\text { The tourist spots were } \\
\text { approximately } 10 \mathrm{~km} \text { from the } \\
\text { high way or developed roads. } \\
\text { (Distance) }\end{array}$ & 2.54 & Agree \\
\hline $\begin{array}{l}\text { The travel time for tourist spots } \\
\text { were within an hour from a } \\
\text { nearby city. (Travel Time) }\end{array}$ & 2.57 & Agree \\
\hline $\begin{array}{l}\text { The road is made of asphalt or } \\
\text { concrete or any similar } \\
\text { materials that will not result to } \\
\text { unpaved surface. (Type of } \\
\text { Road) }\end{array}$ & $\begin{array}{l}\text { Strongly } \\
\text { Disagree }\end{array}$ \\
\hline $\begin{array}{l}\text { There are vehicles available } \\
\text { anytime of the day that are } \\
\text { exclusively for tourist spots. } \\
\text { (Means of Transport) }\end{array}$ & & Disagree \\
\hline Total Weighted Mean & 2.13 & Disagree \\
\hline
\end{tabular}

Table 2 presents that the statement, "The travel time for tourist spots were within an hour from a nearby city" which represents Travel Time got the highest weighted mean of 2.57 with verbal interpretation, "Agree." While the statement, "The road is made of asphalt or concrete or any similar materials that will not result to unpaved surface" which represents the type of roadgot the lowest weighted mean of 1.44 with verbal interpretation, "Strongly Disagree."

\section{Table 3. Tourist spots' Products and Services}

\begin{tabular}{|l|l|l|}
\hline Statements & $\begin{array}{l}\text { Weighted } \\
\text { Mean }\end{array}$ & $\begin{array}{l}\text { Verbal } \\
\text { Interpretation }\end{array}$ \\
\hline $\begin{array}{l}\text { There were four or more } \\
\text { tourism activities available on } \\
\text { a certain tourist spot. }\end{array}$ & $\begin{array}{l}\text { Strongly } \\
\text { Agree }\end{array}$ \\
\hline $\begin{array}{l}\text { There were four or more } \\
\text { varieties of products offered } \\
\text { on a certain tourist spot. }\end{array}$ & Agree \\
\hline $\begin{array}{l}\text { There were 6 or more } \\
\text { facilities available for } \\
\text { tourists/visitors on a certain } \\
\text { tourist spot. }\end{array}$ & Disagree \\
\hline $\begin{array}{l}\text { There were } 6 \text { or more } \\
\text { services offered for } \\
\text { tourists/visitors on a certain } \\
\text { tourist spot. }\end{array}$ & & Disagree \\
\hline Total Weighted Mean & 2.18 & Disagree \\
\hline
\end{tabular}


Table 3 presents that the statement, "There were four or more tourism activities available on a certain tourist spot" got the highest weighted mean of 3.38 with verbal interpretation, "Strongly Agree." While the statement, "There were 6 or more facilities available for tourists/visitors on a certain tourist spot." which represents the presence of visitor traffic got the lowest weighted mean of 2.81 with verbal interpretation, "Disagree."

Table 4. Summary Mean Ratings of Tourist Spot Evaluation

\begin{tabular}{|l|l|l|}
\hline & $\begin{array}{l}\text { Weighted } \\
\text { Mean }\end{array}$ & $\begin{array}{l}\text { Verbal } \\
\text { Interpretation }\end{array}$ \\
\hline Tourist Appeal & 3.24 & Excellent \\
\hline Accessibility & 2.13 & Fair \\
\hline $\begin{array}{l}\text { Availability of products } \\
\text { and services }\end{array}$ & 2.60 & Good \\
\hline Total Weighted Mean & 2.66 & Good \\
\hline
\end{tabular}

Table 4 presents the summary mean ratings of tourist spot evaluation. The tourist appeal got the highest weighted mean of 3.24 with verbal interpretation, "Excellent." While the accessibility for tourists got the lowest weighted mean of 2.13 with verbal interpretation, "Fair."

Table 5. Transportation (Area of Development)

\begin{tabular}{|l|l|l|}
\hline Transportation & $\begin{array}{l}\text { Weighted } \\
\text { Mean }\end{array}$ & $\begin{array}{l}\text { Verbal } \\
\text { Interpretation }\end{array}$ \\
\hline $\begin{array}{l}\text { The travel time from airport } \\
\text { or seaport to a tourism center } \\
\text { or town is less than an hour. }\end{array}$ & 1.44 & $\begin{array}{l}\text { Strongly } \\
\text { Disagree }\end{array}$ \\
\hline $\begin{array}{l}\text { There is a well-established } \\
\text { airport or main seaport that } \\
\text { can expand easily for future. }\end{array}$ & 1.89 & Disagree \\
\hline $\begin{array}{l}\text { The transport services at } \\
\text { airport or main seaport meet } \\
\text { international standard and } \\
\text { operation. }\end{array}$ & 2.04 & Disagree \\
\hline $\begin{array}{l}\text { The conditions of road from } \\
\text { town to a tourism center is } \\
\text { paved and more than 7m-wide } \\
\text { carriageway. }\end{array}$ & 2.73 & Agree \\
\hline Total Weighted Mean & 2.03 & Disagree \\
\hline
\end{tabular}

Table 5 presents that the statement, "The conditions of road from town to a tourism center is paved and more than $7 \mathrm{~m}$ wide carriageway" got the highest weighted mean of 2.73 with verbal interpretation, "Agree." While the statement, "The travel time from airport or seaport to a tourism center or town is less than an hour" got the lowest weighted mean of 1.44 with verbal interpretation, "Strongly Disagree."

Table 6. Tourism Service Facility (Area of Development)

\begin{tabular}{|l|l|l|}
\hline Tourism service facility & $\begin{array}{l}\text { Weighted } \\
\text { Mean }\end{array}$ & $\begin{array}{l}\text { Verbal } \\
\text { Interpretation }\end{array}$ \\
\hline $\begin{array}{l}\text { There were guide signs and } \\
\text { information board provided } \\
\text { along the road for tourists. }\end{array}$ & 3.75 & $\begin{array}{l}\text { Strongly } \\
\text { Agree }\end{array}$ \\
\hline $\begin{array}{l}\text { There is an information center } \\
\text { with shops and comfort } \\
\text { rooms at the tourism center or } \\
\text { town. }\end{array}$ & $\begin{array}{l}\text { Strongly } \\
\text { Agree }\end{array}$ \\
\hline $\begin{array}{l}\text { There were a more than 500 } \\
\text { rooms in total of } \\
\text { accommodation } \\
\text { establishments for tourists. }\end{array}$ & 2.83 & Agree \\
\hline \begin{tabular}{l} 
Total Weighted Mean \\
\hline
\end{tabular} & 3.28 & $\begin{array}{l}\text { Strongly } \\
\text { Agree }\end{array}$ \\
\hline
\end{tabular}

Table 6 presents that the statement, "There were guide signs and information board provided along the road for tourists" got the highest weighted mean of 3.75 with verbal interpretation, "Strongly Agree." While the statement, "There were a more than 500 rooms in total of accommodation establishments for tourists" got the lowest weighted mean of 2.83 with verbal interpretation, "Agree."

Table 7. Infrastructure (Area of Development)

\begin{tabular}{|l|l|l|}
\hline Infrastructure & $\begin{array}{l}\text { Weighted } \\
\text { Mean }\end{array}$ & $\begin{array}{l}\text { Verbal } \\
\text { Interpretation }\end{array}$ \\
\hline $\begin{array}{l}\text { There is a water supply/water } \\
\text { resource/ water plant nearby } \\
\text { tourism spots or town. }\end{array}$ & 3.42 & $\begin{array}{l}\text { Strongly } \\
\text { Agree }\end{array}$ \\
\hline $\begin{array}{l}\text { There is an operating } \\
\text { sewerage system and solid } \\
\text { waste collection nearby } \\
\text { tourism spots or town. }\end{array}$ & 3.16 & Agree \\
\hline $\begin{array}{l}\text { There is a power } \\
\text { supply/power plant nearby } \\
\text { tourism spots or town. }\end{array}$ & 3.10 & Agree \\
\hline $\begin{array}{l}\text { All means of } \\
\text { telecommunication are } \\
\text { available nearby tourism spots } \\
\text { or town. }\end{array}$ & 2.87 & Agree \\
\hline Total Weighted Mean & 3.13 & Agree \\
\hline
\end{tabular}


Table 7 presents that the statement, "There is a water supply/water resource/ water plant nearby tourism spots or town" got the highest weighted mean of 3.42 with verbal interpretation, "Strongly Agree." While the statement, "All means of telecommunication are available nearby tourism spots or town" got the lowest weighted mean of 2.87 with verbal interpretation, "Agree."

Table 8. Summary of Mean Ratings of Tourism Areas for Development

\begin{tabular}{|l|l|l|}
\hline & $\begin{array}{l}\text { Weighted } \\
\text { Mean }\end{array}$ & $\begin{array}{l}\text { Verbal } \\
\text { Interpretation }\end{array}$ \\
\hline Transportation & 2.03 & Fair \\
\hline $\begin{array}{l}\text { Tourism Service } \\
\text { Facility }\end{array}$ & 3.28 & Excellent \\
\hline Infrastructure & 3.13 & Good \\
\hline Total Weighted Mean & 2.81 & Good \\
\hline
\end{tabular}

Table 8 presents the summary mean ratings of tourism areas for development. Tourism service facility got the highest weighted mean of 3.28 with verbal interpretation, "Excellent." While the transportation for tourists got the lowest weighted mean of 2.13 with verbal interpretation, "Fair."

\section{CONCLUSION}

In light of the foregoing results, the researcher concluded that the tourist spots in Nueva Ecija greatly appealed its visitors through its uniqueness, historical value and natural aesthetics and were evaluated as "Excellent." Thus, the accessibility to these tourist spots were evaluated as "Fair." The researcher recommends that the government sector should focus on road development to increase in propagation of tourism.

Further, the difficulties and problems encountered by tourists, in terms of "Transportation" was evaluated as "Fair." Thus, the areas for the development of tourism should focus more on improving the aspect transportation than tourism service facility as this aspect was evaluated as "Excellent."

\section{REFERENCES}

[1] Aguila, G. M., \&Ragot, R. (2014). Ecotourism industry in Ilijan Batangas City, Philippines: Assessing its effects as a basis of proposed tourism development plan. Quarterly Journal of Business Studies, 1(1), 24-35.

[2] Celis, M. I., Mendoza, E. E., \& Baruc, M. M. (2013). Tourist Attraction in the CALABARZON Region, Philippines: Basis for Strategic Planning. International Journal of Academic Research in Business and Social Sciences, 3(8), 2222-6990.

[3] Cohen, L., Manion, L., \& Morrison, K. (2002). Research methods in education. routledge.

[4] De Vera, M. (2019, July). Localized Effective Tourism Carrying Capacity using Tourist Proxemics and Corrective Factors, The Case of Sabang Beach in Baler, Aurora, Philippines. In IOP Conference Series: Earth and Environmental Science (Vol. 294, No. 1, p. 012016). IOP Publishing.

[5] Jian-ying, G. U. O. (2007). Assessing the Tourism Value of Tourism Resources of Leshan Grand Buddha [J]. Areal Research and Development, 6, 104-107.

[6] Lickorish, L. J., \& Jenkins, C. L. (2007). Introduction to tourism. Routledge.

[7] Said, H. M. (2008, July). Planning for sustainable tourism in Pulau Gaya, Sabah: preliminary assessment of natural resources, community, culture and their implications for future tourism development. In Proceedings of Natural Symposium on Tourism Research (Vol. 26, pp. 21-27).

[8] Su, M. M., \& Wall, G. (2010). Implications of host-guest interactions for tourists' travel behaviour and experiences. Turizam: međunarodniznanstvenostručničasopis, 58(1), 37-50.

[9] Vagias, W. M. (2006). Likert-type scale response anchors. clemson international institute for tourism. \& Research Development, Department of Parks, Recreation and Tourism Management, Clemson University.

[10] Ylagan, A. P., \& Laguador, J. M. (2014). Tourism Studies in the Province of Batangas, Philippines: A. International Journal of Management, 4(10), 421-428. 